第 38 回日本内分泌学会東北支部学術集会は、第 92 回日本内分泌学会学術総会と同時開催されましたので、日本 内分泌学会雑誌 95 巻 1 号に掲載されています。

プログラム

https://www.jstage.jst.go.jp/article/endocrine/95/1/95_41/_article/-char/ja

抄録

https://www.jstage.jst.go.jp/article/endocrine/95/1/95_173/_pdf/-char/ja

\title{
特別講演 14
}

福島第一原発事故後の福島甲状腺超音波検診による小児若年者甲状腺癌について

Childhood and adolescent thyroid cancer occurrence by the Fukushima thyroid ultrasound screening after the Fukushima Daiichi Nuclear Power Plant Accident

鈴木 眞一

福島県立医科大学 医学部 甲状腺内分泌学講座

日本内分泌学会東北支部／東北内分泌研究会 特別シンポジウム 福島県における甲状腺検診の現況、課題と今 後

- TE-1

福島県における基本調査と甲状腺検査の概要

Outline of the Basic Survey and Thyroid Ultrasound Examination in the Fukushima Health Management Survey

神谷 研二 1,2

1 福島県立医科大学 放射線医学県民健康管理センター、2 広島大学 医療政策室

- TE-2

福島県県民健康調査「甲状腺検査」のこれまでの歩みとこれからの課題

Current progress and future of Thyroid Ultrasound Examination in Fukushima Health Management Survey 志村 浩己 ${ }^{1,2}$

1 福島県立医科大学 医学部 臨床検査医学講座、2 福島県立医科大学 放射線医学県民健康管理センター

- TE-3

福島甲状腺検査で発見された小児甲状腺癌症例の病理組織学的特徵

Histopathological features of childhood thyroid cancer detected during screening examinations in Fukushima 長沼 廣 $^{1}$ 、廣川 満良 ${ }^{2}$ 、伊東 正博 $^{3}$ 、坂本 穆彦 ${ }^{4}$ 、橋本 優子 ${ }^{5}$

1 仙台赤十字病院・病理、 ${ }^{2}$ 隈病院・病理、 ${ }^{3}$ 長崎医療センター・病理、 ${ }^{4}$ 大森赤十字病院・病理、 ${ }^{5}$ 福島県 立医科大学・病理

- TE-4

福島県の若年者甲状腺癌に見られる遺伝子変異

Genetic alterations in young thyroid cancer cases in Fukushima

光武 範吏 1,2 、岩館 学 2、松瀬 美智子 1 、Vladimir Saenko ${ }^{3}$ 、鈴木 眞一 2、山下 俊一 ${ }^{1,4}$

1 長崎大学 原研医療、 2 福島県立医科大学 甲状腺内分泌、 ${ }^{3}$ 長崎大学 原研疫学、 4 福島県立医科大学 